\title{
CoNi Nanoparticles/CNT Composite as Effective Anode for Direct Urea Fuel Cells
}

\author{
Nasser A. M. Barakat ${ }^{1,2, *}$, Mohannad Alajami ${ }^{1}$, Zafar Khan Ghouri ${ }^{3}$, Saeed Al-Meer ${ }^{3 *}$ \\ ${ }^{1}$ Bionanosystem Engineering Department, Chonbuk National University, Jeonju 561-756, Republic of \\ Korea \\ ${ }^{2}$ Chemical Engineering Department, Faculty of Engineering, Minia University, El-Minia, Egypt \\ ${ }^{3}$ Central Laboratories Unit, Qatar University, P.O.Box:2713, Doha, Qatar \\ *E-mail: nasser@jbnu.ac.kr
}

Received: 16 January 2018 / Accepted: 28 February 2018 / Published: 10 April 2018

CoNi nanoparticles/CNTs composite is introduced as workable anode in the direct urea fuel cells. The proposed anode was prepared by calcination under argon atmosphere of a dried cobalt acetate/nickel acetate/CNTs/ethanol slurry at $850{ }^{\circ} \mathrm{C}$. The composition of the metal nanoparticles was optimized by synthesizing composites having different cobalt contents compared to nickel. The results indicated that the best performance is attributed to the anode containing nanoparticles having $10 \mathrm{wt} \% \mathrm{Co}$ as the corresponding generated power was $3.95 \mathrm{~mW} / \mathrm{m}^{2}$ which is 40 folds compared to that obtained from pristine nickel nanoparticles-containing anode $\left(0.09 \mathrm{~mW} / \mathrm{m}^{2}\right)$.

Keywords: Direct urea fuel cells; CoNi/CNTs composites; Urea oxidation.

\section{INTRODUCTION}

Besides the human and animal urines, fertilizers industries discharge huge amount of ureacontaminated wastewaters. The urea fertilizer manufacturing plants discharge $0.75 \mathrm{~m}^{3}$ wastewater containing around $1 \mathrm{wt} \%$ urea per ton fertilizer produced [1]. Environmentally, the urea-polluted water should be treated to avoid formation of the ammonia gas from urea hydrolysis [2].

$$
\mathrm{NH}_{2} \mathrm{CONH}_{2}+\mathrm{H}_{2} \mathrm{O} \longrightarrow 2 \mathrm{NH}_{3}+\mathrm{CO}_{2}
$$

Besides the air pollution which may result in falling the acidic rains, the produced ammonium can create other environmental problems. The dissolved ammonia is biologically oxidized in water by two kinds of microorganisms (Nitrobacter and Nitrosomonas) to nitrate $\left(\mathrm{NO}_{3}\right)$ in a process called 
nitrification[3]. The main problem is producing a dangerous unstable compound as an intermediate; nitrogen dioxide. This process takes place in the oxygen-containing media such as open water surfaces so the nitrate ion can be reduced to form different kinds of nitrogenous gases. Beside the aforementioned problems, domoic acid which is deadly toxin can be produced by some kinds of ocean algae in the urea-polluted media [4].

Owing considerable amount of hydrogen $(6.67 \mathrm{wt} \%)$ drew the attention of the researchers to exploit the urea-containing wastewater as a good source of hydrogen gas. Therefore, electrolysis has been proposed as a treatment process for the urea-containing wastewater and simultaneously producing $\mathrm{H}_{2}$ gas due to occurring some oxidation reactions which can be explained electrochemically as follow [5-7]:

$$
\begin{array}{llr}
\text { Anode: } & \mathrm{CO}\left(\mathrm{NH}_{2}\right)_{2}+6 \mathrm{OH}^{-} \longrightarrow \mathrm{N}_{2}+5 \mathrm{H}_{2} \mathrm{O}+\mathrm{CO}_{2}+6 \mathrm{e} & \mathrm{E}^{0}=-0.746 \mathrm{~V} \\
\text { Cathode: } & 6 \mathrm{H}_{2} \mathrm{O}+6 \mathrm{e} \longrightarrow 3 \mathrm{H}_{2}+6 \mathrm{OH}^{-} & \mathrm{E}^{0}=-0.829 \mathrm{~V} \\
\text { Overall: } & \mathrm{CO}\left(\mathrm{NH}_{2}\right)_{2}+\mathrm{H}_{2} \mathrm{O} \longrightarrow \mathrm{N}_{2}+3 \mathrm{H}_{2}+\mathrm{CO}_{2} & \mathrm{E}^{0}=-0.083 \mathrm{~V}
\end{array}
$$

As it might be concluded from the standard potentials, the electrolysis process needs small energy however, practically, due to the high overpotentials, the real electrode potentials are very far from the theoretical ones especially the anode potential even with the precious metals anodes[8]. Therefore, the electrolysis process needs high energy and it is economically not preferable.

Developing a proper anode material can lead to operate direct urea fuel cells (DUFC) in which the urea is oxidized and simultaneously the wastewater will be treated. In the DUFC, the electrodes reactions will be in these forms [9].

$$
\begin{array}{lr}
\text { Cathode: } 2 \mathrm{H}_{2} \mathrm{O}+\mathrm{O}_{2}+4 \mathrm{e} \longrightarrow 4 \mathrm{OH}^{-} & \mathrm{E}^{0}=+0.40 \mathrm{~V} \\
\text { Anode: } \mathrm{CO}\left(\mathrm{NH}_{2}\right)_{2}+6 \mathrm{OH}^{-} \longrightarrow \mathrm{N}_{2}+5 \mathrm{H}_{2} \mathrm{O}+\mathrm{CO}_{2}+6 \mathrm{e} & \mathrm{E}^{0}=-0.746 \mathrm{~V} \\
\text { Overall: } 2 \mathrm{CO}\left(\mathrm{NH}_{2}\right)_{2}+3 \mathrm{O}_{2} \longrightarrow 2 \mathrm{~N}_{2}+4 \mathrm{H}_{2} \mathrm{O}+2 \mathrm{CO}_{2} & \mathrm{E}^{0}=+1.146 \mathrm{~V}
\end{array}
$$

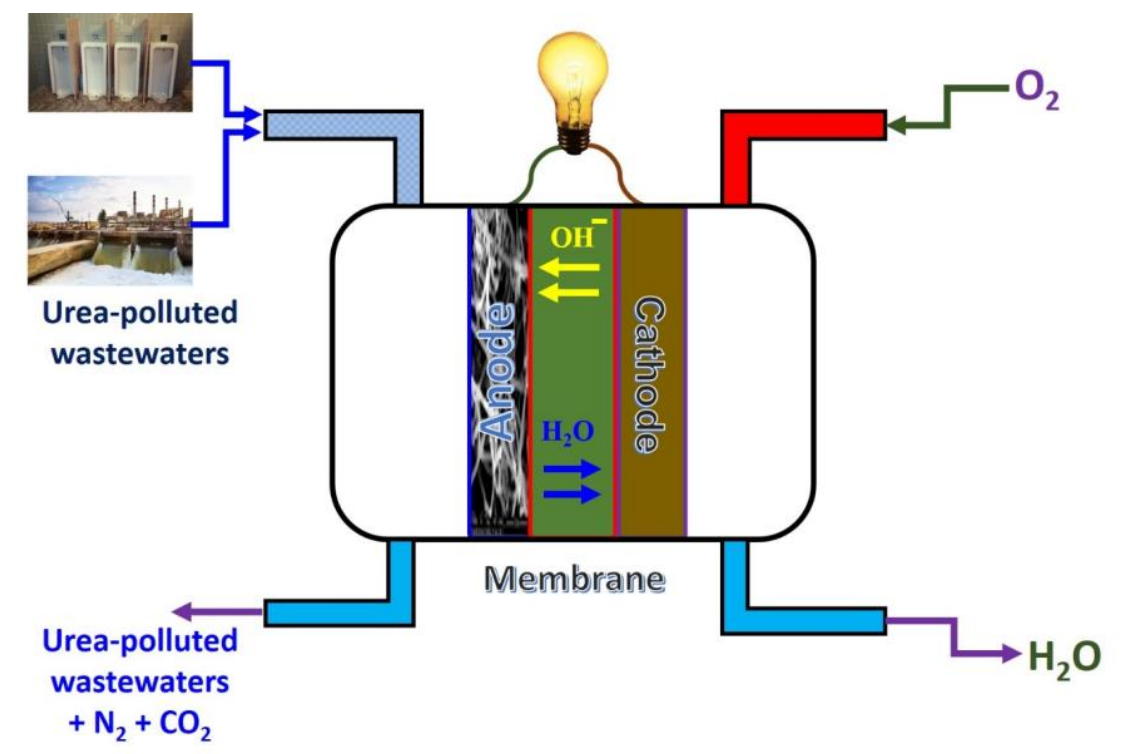

Figure 1. Schematic diagram for the utilization of the direct urea fuel cells. 
Fig. 1 displays a schematic diagram for the applications of the direct urea fuel cells. Although precious metals show unmatched activities toward the oxidation of alcohols and light organic acids, they possess low activity toward urea oxidation. Surprisingly, compared to the precious metals, nickel shows better activities toward urea electrooxidation. However, based to several reports, pristine nickel owns unworkable anode onset potential for the fuel cells as it is higher than the cathode potential (Eq. 6) which constrains the practical application $[10,11]$. Therefore, to develop a practically acceptable anode for the DUFC, co-catalysts have been incorporated with the nickel to decrease the onset potential [8, 12]. Moreover, the carbonaceous supports strongly improved the electro catalytic performance of the catalysts [13]

In this study, CoNi nanoparticles/CNT composite is introduced as a workable anode in DUFC. The results indicated that the composition of the metal nanoparticles has distinct influence on the generated power as the nanoparticles having $10 \mathrm{wt} \%$ cobalt showed the best performance.

\section{METHODS}

Commercial multiwall carbon nanotubes (dimeter $15 \mathrm{~nm}$ and length $5 \mu \mathrm{m}$, Carbon NanoMaterials Technology Co. South Korea) were used without any treatment. Cobalt (II) acetate tetrahydrate (CoAc; 98\% assay, Junsei Chemical Co., Japan) and nickel (II) acetate tetra-hydrate (NiAc; $98 \%$, Aldrich Co., USA) were utilized as metals precursors. Synthesis of the introduced electrocatalyst was conducted by first weighing $100 \mathrm{mg}$ of the metal acetates (cobalt acetate tetrahydrate and nickel acetate tetrahydrate) with different ratios. Typically, CoAc:NiAc weight ratios were kept as 0:100, 10:90, 20:80, 40:60, 60:40, 80:20 and 100:0, so the final composites were abbreviated as $\mathrm{Co}_{0 \%} \mathrm{Ni}_{100 \%}, \mathrm{Co}_{10 \%} \mathrm{Ni}_{90 \%}, \mathrm{Co}_{20 \%} \mathrm{Ni}_{80 \%}, \mathrm{Co}_{40 \%} \mathrm{Ni}_{60 \%}, \mathrm{Co}_{60 \%} \mathrm{Ni}_{40 \%}, \mathrm{Co}_{80 \%} \mathrm{Ni}_{20 \%}$, $\mathrm{Co}_{100 \%} \mathrm{Ni}_{0 \%}$. The estimated precursors were dissolved in $10 \mathrm{ml}$ absolute ethanol (SamChun Chemicals Co., South Korea), then $50 \mathrm{mg}$ of the CNT was added to the solution, the slurry was sonicated for 30 min. Later on, the ethanol was evaporated at $80{ }^{\circ} \mathrm{C}$ and the samples were kept for full drying at the same temperature for $3 \mathrm{~h}$. The calcination process was performed under Ar atmosphere at $850{ }^{\circ} \mathrm{C}$ with $3 \mathrm{~h}$ holding time.

Passive fuel cell with a $23 \mathrm{ml}$ fuel tank was used to check the performance of the introduced composites. Carbon felt $(2.4 \mathrm{~cm} \times 2.4$, Alfa Aesar) was used as a diffusion layer (DL). A slurry composed of $0.5 \mathrm{wt} \%$ of the electrocatalyst, $5 \mathrm{wt} \%$ Nafion solution (5 wt $\%$, Sigma Aldrich) and 94.5 $\mathrm{wt} \%$ isopropanol was sonicated for $30 \mathrm{~min}$ and exploited as the active ink. The deposition process on the DL was carried out by a micropipette. After deposition the anode was dried at $80{ }^{\circ} \mathrm{C}$ for $30 \mathrm{~min}$. The catalyst loading was kept at $0.5 \mathrm{mg} / \mathrm{cm}^{2}$. The cathode was $2.4 \mathrm{~cm} \times 2.4 \mathrm{~cm}$ Pt-loaded $\left(0.5 \mathrm{mg} / \mathrm{cm}^{2}\right)$ carbon paper (EC-20-5, Electro Chem, Inc., USA). Anion exchange membrane (AEM, Membrane International Inc., NJ, USA) was used. The membrane was firstly treated by dipping in an $\mathrm{KOH}$ solution $(0.5 \mathrm{M})$ for $18 \mathrm{~h}$, and then kept in distilled water. The current collectors were two gold-plated $0.1 \mathrm{~cm}$ thick high corrosion resistance stainless steel plates. The polarization curves were estimated at scan rate of $1 \mathrm{mV} / \mathrm{s}$. The electrochemical measurements were conducted by VersaStat-4 Potentiostat/Galvanostat (AMETEK, USA). Rigaku X-ray diffractometer (XRD, Rigaku, Japan) with 
$\mathrm{Cu} \mathrm{K \alpha}(\lambda=1.540 \AA)$ radiation over Bragg angle ranging from 10 to $100^{\circ}$ was utilized to study the chemical structure change after performing the thermal treatment process. The morphology of the proposed composite was investigated by Scanning Electron Microscope (SEM, JEOL JEM-2010, Japan).

\section{RESULTS AND DISCUSSION}

Based on literature, calcination of some transition metal acetates (especially cobalt and nickel) under inert atmosphere leads to produce the zero-valence metals instead of the expected metallic compounds (e.g. oxides) due to formation of strong reducing gases $\left(\mathrm{CO}\right.$ and $\left.\mathrm{H}_{2}\right)$ [14, 15].

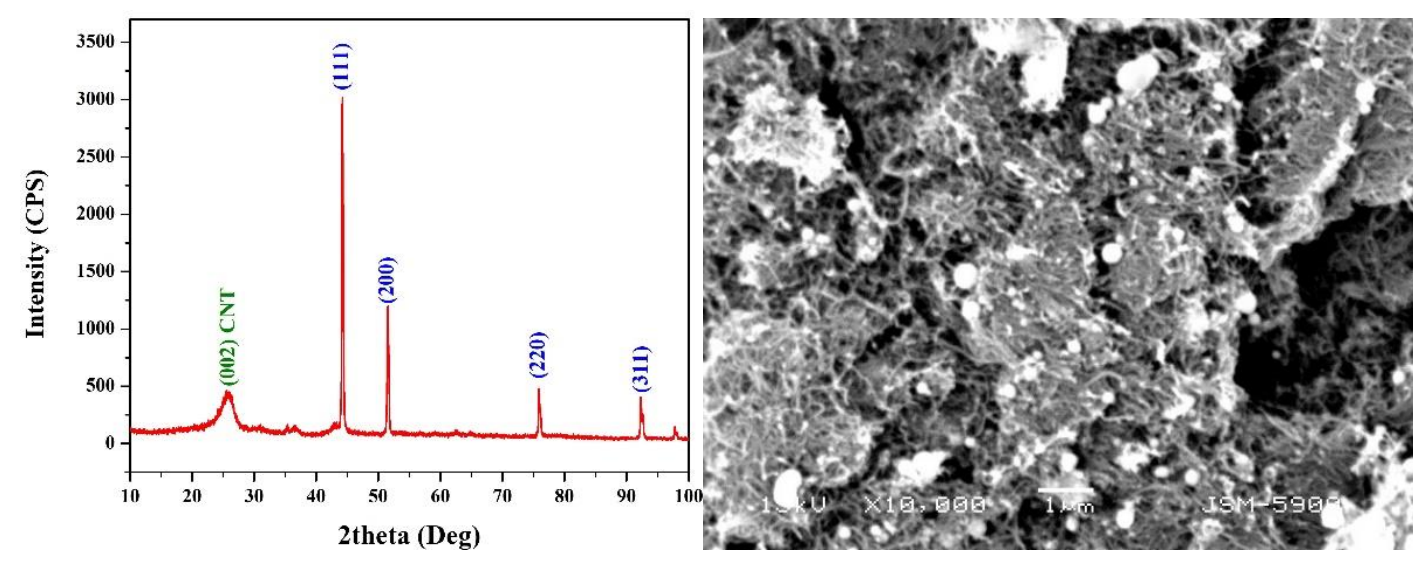

Figure 2. XRD pattern; (A) and SEM image; (B) of the CoNi nanoparticles / CNT composite. The Miller indices of the crystal were added in the XRD pattern

Therefore, it is understandable to get the identification peaks of nickel and cobalt in the XRD pattern (Fig. 2A) of the introduced composite (50\% cobalt acetate sample). Nickel and cobalt are neighbors in the periodic table so they have close lattice parameters and accordingly close standard identification peaks in the XRD database. Typically, in the XRD pattern, cobalt can be distinguished by appearance of diffraction peaks at 2theta values of $44.2^{\circ}, 51.5^{\circ}, 75.8^{\circ}$ and $92.2^{\circ}$ corresponding to (1 1 1), ( $\left.\begin{array}{lll}2 & 0 & 0\end{array}\right),\left(\begin{array}{lll}2 & 2 & 0\end{array}\right)$ and (3 111 ) crystal planes, respectively (PDF\# 15-0806). On the other hand, the standard peaks of nickel can be detected at 2 theta values of $44.5^{\circ}, 51.8^{\circ}, 76.3^{\circ}$ and $92.9^{\circ}$ corresponding to (1 11 1), (2 $\left.\begin{array}{lll}2 & 0\end{array}\right),\left(\begin{array}{lll}2 & 2 & 0\end{array}\right)$ and ( $\left.\begin{array}{lll}3 & 1 & 1\end{array}\right)$ crystal planes, respectively (PDF\# 04-0850). Therefore, based on the obtained XRD pattern for the introduced composite (Fig. 2A), it can be claimed that the used metal precursors have been totally reduced to the corresponding metals which matches the previous studies. Accordingly, the nanoparticles appeared in the SEM image (Fig. 2B) can be assigned to the CoNi nanoparticles.

Cobalt showed good performance as a co-catalyst with nickel as it distinctly decreases the onset potential with urea and alcohols $[12,16]$. However, it can be expected that the cobalt content can have an impact on the catalyst performance, so different metal nanoparticles were prepared by changing the cobalt acetate content in the initial solution starting from 0 to $100 \mathrm{wt} \%$ with respect to nickel acetate. Fig. 3 shows the polarization curves for DUFCs having different anodes based on the 
metal nanoparticles composition. As shown in the figure, the composite having pristine nickel nanoparticles/CNT $\left(\mathrm{Co}_{0 \%} \mathrm{Ni}_{100 \%} / \mathrm{CNT}\right)$ reveals trivial open circuit potential $(\mathrm{OCV} ; 0.028 \mathrm{~V})$ which supports the previous studies. On the other hand, pure cobalt nanoparticles/CNT $\left(\mathrm{Co}_{100 \%} \mathrm{Ni}_{0 \%} / \mathrm{CNT}\right)$ showed better performance as the corresponding OCV equals $0.06 \mathrm{~V}$. It is noteworthy mentioning that the pristine cobalt nanoparticles demonstrated good performance toward methanol oxidation [17]. This study proves that pure cobalt has also good electocatalytic performance to improve the oxidation of urea process. However, the obtained results in Fig. 3 indicated that the best performance is attributed to the nanoparticles having $\mathrm{Co}_{10 \%} \mathrm{Ni}_{90 \%} / \mathrm{CNT}$ as the $\mathrm{OCV}$ of the corresponding cell is $0.17 \mathrm{~V}$.

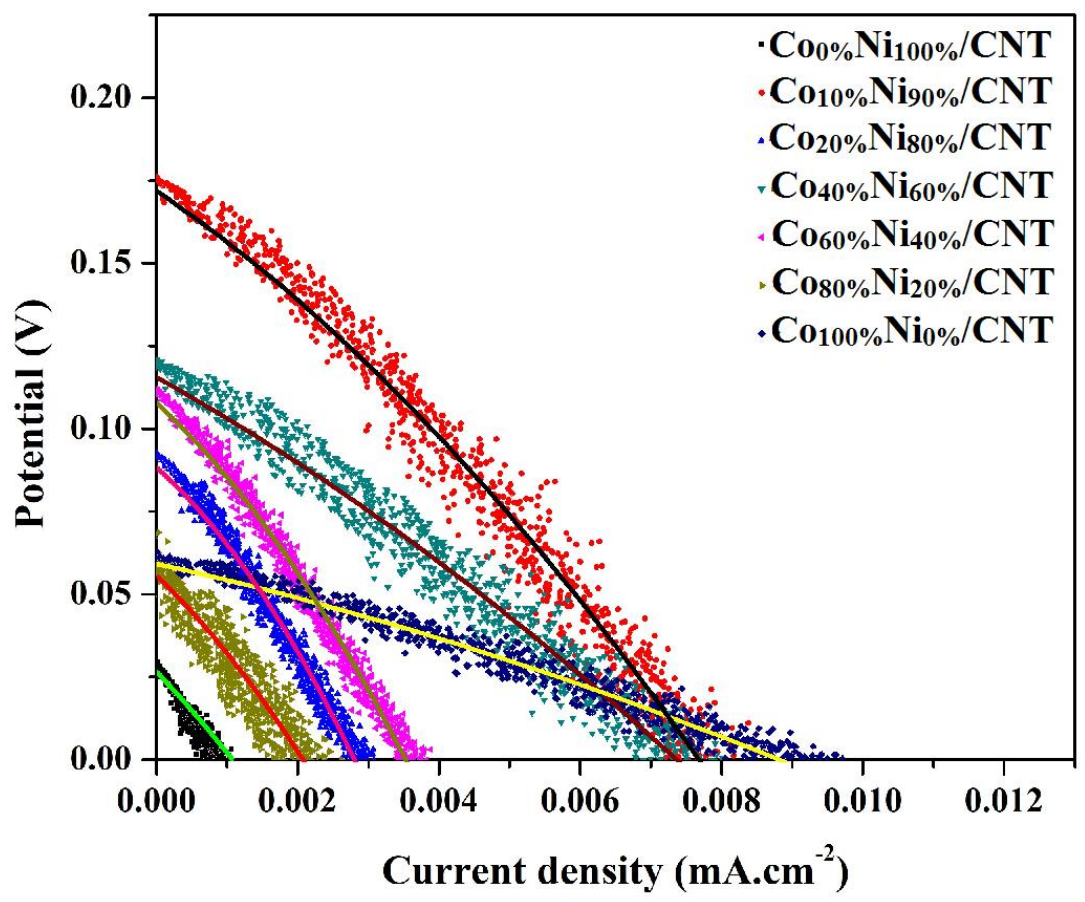

Figure 3. Polarization curve for the direct fuel cell using different composition metal nanoparticle/CNT anodes: Real data and the corresponding polynomial fittings. The polarization curves have been measured at $1 \mathrm{mV} / \mathrm{s}$ scan rate at room temperature $\left(\sim 17{ }^{\circ} \mathrm{C}\right)$. Normalization of the current was carried out with respect to the anode apparent surface area.

Fig. 4 showed the power densities curves for the assembled DUFCs. As shown, a maximum power density of $3.95 \mathrm{~mW} / \mathrm{m}^{2}$ with a corresponding current density of $0.00395 \mathrm{~mA} / \mathrm{cm}^{2}$ was obtained with the anode having nanoparticles containing $\mathrm{Co}_{10 \%} \mathrm{Ni}_{90 \%} / \mathrm{CNT}$. Actually, compared to other fuel cells, DUFCs show low power because of the internal resistance of the fuel cell which is the most effective parameter on the produced power. Using commercial the anion exchange membrane is the main reason behind the high internal resistance. The internal resistance can be estimated from the power density peak as the maximum power is generated where the internal resistance is marching to the external load (resistance)[18]. Accordingly, the internal resistance can be identified by determining the external resistance which causes to obtain the observed peak in the polarization curve. The external resistance can be estimated from $R_{e x t}=P_{\text {max }} / I^{2}$. Accordingly, the internal resistance was calculated for the $\mathrm{Co}_{10 \%} \mathrm{Ni}_{90 \%} / \mathrm{CNT}$ composite as $110 \mathrm{Ohm}$. Although, compared to direct alcohol fuel cells, the produced power looks small; it is believed that this is a good finding as a power could be generated 
from wastewater with a simultaneous treatment. It is noteworthy mentioning that CoNi nanoparticles were previously exploited as an anode material for the direct urea fuel cells, in that study the metallic nanoparticles were supported in black carbon with relatively complicated synthesis procedure compared to what introduced in this study [12]. Although, the metal content in the introduced composite ( $23 \mathrm{wt} \%$ ) compared to that study (50 wt\%), the obtained efficiency is comparable. Moreover, the proposed composite reveals higher activity as anode material in the real direct urea fuel cells compared to Ni-decorated graphene which was introduced in our previous study [19]. However, lower activity is associated compared to pristine nano-sized nickel anode [20].

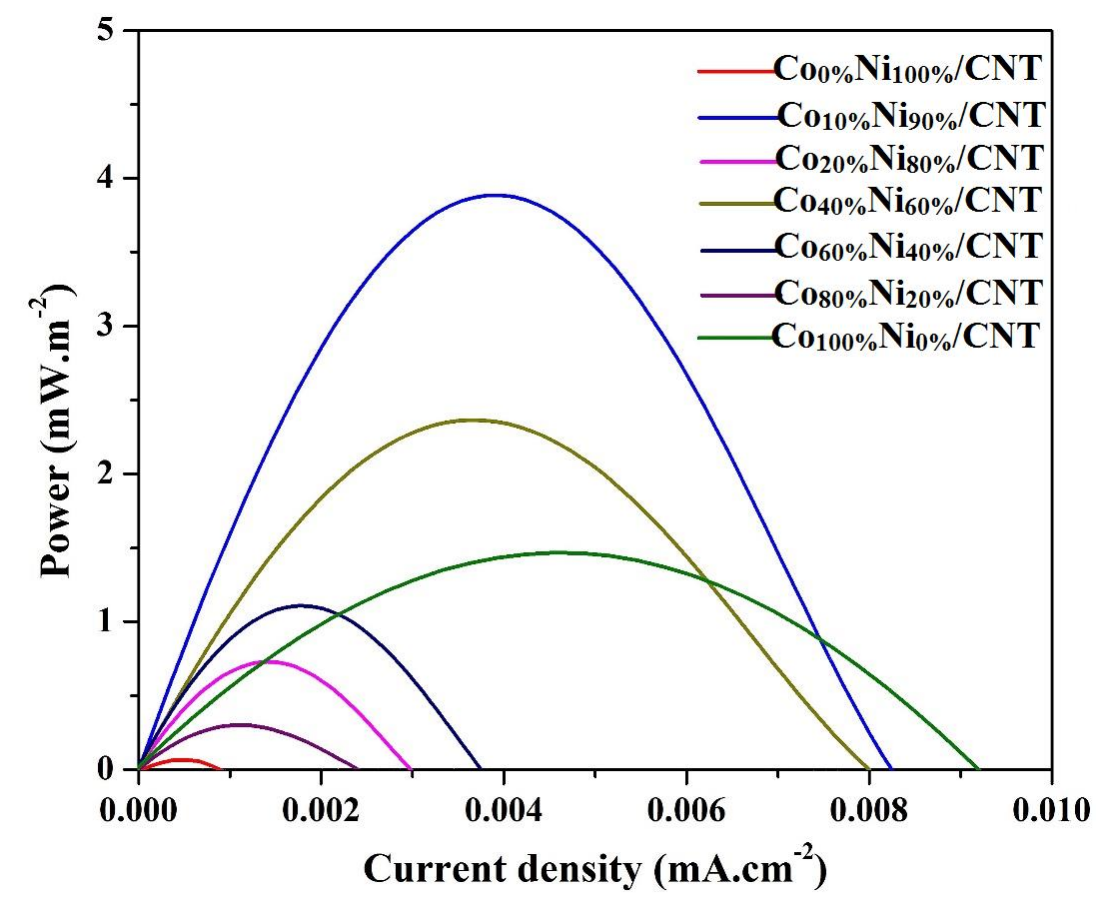

Figure 4. Power density curves for direct fuel cells using different composition metal nanoparticle/CNT anodes. The power density was estimate from the polarization curves which were measured at $1 \mathrm{mV} / \mathrm{s}$ scan rate at room temperature $\left(\sim 17^{\circ} \mathrm{C}\right)$. Normalization of the power was carried out with respect to the anode apparent surface area.

\section{CONCLUSIONS}

CoNi/CNT composite can be synthesized by calcination under argon atmosphere of CNT, cobalt acetate and nickel acetate. The composite can work effectively as anode in direct fuel cells. However, the composition of the metal nanoparticles should be optimized as $\mathrm{Co}_{10 \%} \mathrm{Ni}_{90 \%} / \mathrm{CNT}$ composite reveals the highest performance.

\section{ACKNOWLEDGMENTS}

This Publication was made possible by NPRP grant \# [8-1344-1-246] from the Qatar National Research Fund (a member of Qatar Foundation). The findings achieved herein are solely the responsibility of authors. 


\section{AUTHORS' CONTRIBUTIONS}

NAB conceived the idea of experiments. MA carried out the preparation and characterization of the samples. NAB, ZKG and SM analyzed and discussed the results of the experiments. NAB and SM supervised the project. NAB wrote the manuscript. All authors read and approved the final manuscript.

\section{COMPETING INTERESTS}

The authors declare that they have no competing interests.

\section{References}

1. W. Yan, D. Wang, G.G. Botte, Appl. Catal., B, 127 (2012) 221.

2. S. Kojima, A. Bohner, N. Von Wirén, J. Membr. Biol., 212 (2006) 83.

3. E.D. Ongley, Control of water pollution from agriculture, Food \& Agriculture Org.1996.

4. S. Bargu, M.W. Silver, M.D. Ohman, C.R. Benitez-Nelson, D.L. Garrison, Nat. Geosci., 5 (2012) 2.

5. W. Yan, D. Wang, G.G. Botte, Electrochim. Acta, 61 (2012) 25.

6. R.L. King, G.G. Botte, J. Power Sources, 196 (2011) 9579.

7. D. Wang, W. Yan, S.H. Vijapur, G.G. Botte, Electrochim. Acta, 89 (2013) 732.

8. N.A. Barakat, M. Alajami, Y. Al Haj, M. Obaid, S. Al-Meer, Catal. Commun., 97 (2017) 32.

9. R. Lan, S. Tao, J.T. Irvine, Energ Environ Sci, 3 (2010) 438.

10. D. Wang, G.G. Botte, ECS Electrochem. Lett., 3 (2014) H29.

11. W. Yan, D. Wang, L.A. Diaz, G.G. Botte, Electrochim. Acta, 134 (2014) 266.

12. W. Xu, H. Zhang, G. Li, Z. Wu, Sci. Rep., 4 (2014) 5863.

13. N.A. Barakat, M. Motlak, B.H. Lim, M.H. El-Newehy, S.S. Al-Deyab, J. Electrochem. Soc., 161 (2014) F1194.

14. J.C. De Jesus, I. González, A. Quevedo, T. Puerta, J. Mol. Catal. A: Chem., 228 (2005) 283.

15. N.A. Barakat, K.A. Khalil, I.H. Mahmoud, M.A. Kanjwal, F.A. Sheikh, H.Y. Kim, J Phys Chem C, 114 (2010) 15589.

16. N.A. Barakat, M. Motlak, B.-S. Kim, A.G. El-Deen, S.S. Al-Deyab, A. Hamza, J. Mol. Catal. A: Chem., 394 (2014) 177.

17. N.A. Barakat, M. Motlak, M. Nassar, M.A. Abdelkareem, M. Mahmoud, M.H. El-Newehy, H.M. Moustafa, ECS Electrochem. Lett., 4 (2015) F5.

18. B.E. Logan, Microbial fuel cells, John Wiley \& Sons2008.

19. A. Yousef, M.H. El-Newehy, S.S. Al-Deyab, N.A. Barakat, Arab. J. Chem., 10 (2017) 811.

20. R. Lan, S. Tao, J. Power Sources, 196 (2011) 5021.

(C) 2018 The Authors. Published by ESG (www.electrochemsci.org). This article is an open access article distributed under the terms and conditions of the Creative Commons Attribution license (http://creativecommons.org/licenses/by/4.0/). 